\title{
Biochemical and functional characterization of Plasmodium falciparum DNA polymerase $\delta$
}

Jitlada Vasuvat ${ }^{1}$, Atcha Montree', Sangduen Moonsom¹, Ubolsree Leartsakulpanich², Songsak Petmitr ${ }^{3}$, Federico Focher ${ }^{4}$, George E. Wright ${ }^{5}$ and Porntip Chavalitshewinkoon-Petmitr ${ }^{{ }^{*}}$

\begin{abstract}
Background: Emergence of drug-resistant Plasmodium falciparum has created an urgent need for new drug targets. DNA polymerase $\delta$ is an essential enzyme required for chromosomal DNA replication and repair, and therefore may be a potential target for anti-malarial drug development. However, little is known of the characteristics and function of this $P$. falciparum enzyme.
\end{abstract}

Methods: The coding sequences of DNA polymerase $\delta$ catalytic subunit (PfPol $\delta$-cat), DNA polymerase $\delta$ small subu-

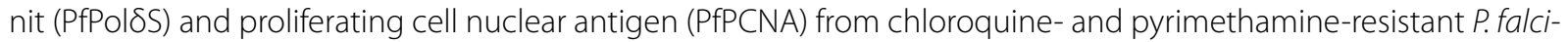
parum strain K1 were amplified, cloned into an expression vector and expressed in Escherichia coli. The recombinant proteins were analysed by SDS-PAGE and identified by LC-MS/MS. PfPol $\delta$-cat was biochemically characterized. The roles of PfPol $\delta S$ and PfPCNA in PfPol $\delta$-cat function were investigated. In addition, inhibitory effects of 11 compounds were tested on PfPol $\delta$-cat activity and on in vitro parasite growth using SYBR Green I assay.

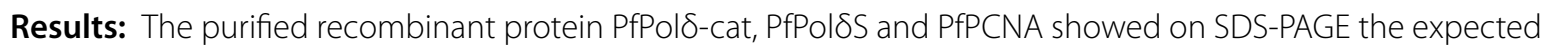

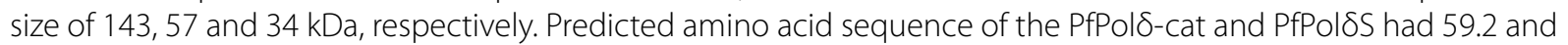
$24.7 \%$ similarity respectively to that of the human counterpart. The PfPol $\delta$-cat possessed both DNA polymerase and $3^{\prime}-5^{\prime}$ exonuclease activities. It used both $\mathrm{Mg}^{2+}$ and $\mathrm{Mn}^{2+}$ as cofactors and was inhibited by high $\mathrm{KCl}$ salt (>200 mM).

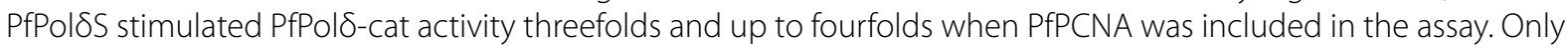
two compounds were potent inhibitors of PfPol $\delta$-cat, namely, butylphenyl-dGTP (BuPdGTP; IC 50 of $38 \mu \mathrm{M})$ and 7-acetoxypentyl-(3, 4 dichlorobenzyl) guanine (7-acetoxypentyl-DCBG; IC 50 of $55 \mu \mathrm{M})$. The latter compound showed higher inhibition on parasite growth $\left(\mathrm{IC}_{50}\right.$ of $\left.4.1 \mu \mathrm{M}\right)$.

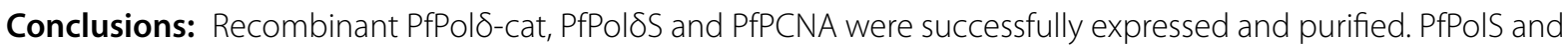
PfPCNA increased DNA polymerase activity of PfPol $\delta$-cat. The high sensitivity of PfPol $\delta$ to BuPdGTP can be used to differentiate parasite enzyme from mammalian and human counterparts. Interestingly, 7-acetoxypentyl-DCBG showed inhibitory effects on both enzyme activity and parasite growth. Thus, 7-acetoxypentyl-DCBG is a potential candidate for future development of a new class of anti-malarial agents targeting parasite replicative DNA polymerase.

Keywords: Plasmodium falciparum, DNA polymerase $\delta$, Drug target, Malaria, Biochemical characterization, Functional characterization

\footnotetext{
*Correspondence: porntip.pet@mahidol.ac.th

${ }^{1}$ Department of Protozoology, Faculty of Tropical Medicine, Mahidol

University, 420/6 Rajvithi Road, Bangkok 10400, Thailand

Full list of author information is available at the end of the article
} 


\section{Background}

Malaria remains one of the major global public health problems in more than 100 endemic countries. Even though the numbers of malaria cases are decreasing, in 2013 there were still 198 million estimated cases globally and 584,000 deaths, mainly among sub-Saharan African children under 5 years of age [1]. Plasmodium falciparum is the most virulent human malaria parasite responsible for the majority of mortality cases. The emergence of anti-malarial resistance, in particular to artemisinins, has become a problem in malarial treatment and control [2-4]. Therefore, a better understanding of parasite metabolism, leading to identification of enzymes essential for its survival, should help in finding new targets for drug development.

One of the chemotherapeutic targets of interest is malarial DNA polymerase, which is an enzyme directly involved in polymerization of deoxynucleotides during replication and/or repair of cellular genetic material [5]. Eukaryotes possess 4 polymerases of the B-family, three of which, namely, DNA polymerase $\alpha(\operatorname{Pol} \alpha)$, DNA polymerase $\delta(\operatorname{Pol} \delta)$ and DNA polymerase $\varepsilon(\operatorname{Pol} \varepsilon)$, are essential enzymes for nuclear DNA replication [6]. Each enzyme plays a role in the replisome complex located at the replication fork, in which Pol $\delta$ replicates the lagging strand after it has been primed by Pol $\alpha$ [7]. Both Pol $\delta$ and Pol $\varepsilon$ are distinguished from Pol $\alpha$ by their $3^{\prime}-5^{\prime}$ proof-reading exonuclease activity, which allows removal of mis-incorporated deoxynucleotides, ensuring a high fidelity of DNA synthesis required for accurate genome replication [6].

Pol $\delta$ holoenzyme participates in replicative synthesis in concert with the processivity factor proliferating cell nuclear antigen (PCNA). Kinetic and binding studies have shown that PCNA increases Pol $\delta$ processivity as well as activity [8], possibly by forming a trimeric closed ring structure, which encircles the DNA and provides a sliding clamp for attachment of Pol $\delta$ [9]. In addition to its function in DNA replication, Pol $\delta$ plays a role in DNA repair and recombination [6]. In base excision repair (BER), one of DNA repair mechanisms of single-stranded DNA damage, Pol $\delta$ is involved in the long-path pathway, whereas Pol $\beta$ plays a role in the short-path pathway [10]. Interestingly, the long-patch BER is predominate in $P$. falciparum while short-path BER is mainly found in humans [11].

Pol $\delta$ has been purified from a number of eukaryotes. In Saccharomyces cerevisiae, Pol $\delta$ is composed of three subunits: catalytic subunit Pol3p and structural subunits Pol31p and Pol32p [12-14]. In Schizosaccharomyces pombe, Pol $\delta$ consists of four subunits: Pol3, Cdc 1 , Cdc27 and Cdm1 [15]. Human and mammalian enzymes initially were characterized as a heterodimer of p125 catalytic and p50 subunits $[16,17]$. The p125 catalytic subunit is homologous to yeast Pol3 and Pol3p, whereas subunit p50 is a homologue of Cdc 1 and Pol31p [18, 19]. Later, two additional subunits of human and mammalian Pol $\delta$ were identified, namely, p68 and p12, displaying significant homology with Schizosaccharomyces pombe Cdc27 and Cdm1 respectively [20, 21]. Unlike mammalian Pol $\delta$ holoenzyme, formed by four subunits [21], only two subunits (p125 catalytic subunit and p50 small subunit) were identified in the Plasmodb sequence database.

Three types of $P$. falciparum DNA polymerases have been identified and characterized: nuclear Pol $\alpha$ and Pol $\beta$ from parasite crude extract $[22,23]$ and Pol $\gamma$ from parasite mitochondria [24]. Plasmodium falciparum (Pf) Pol $\delta$ gene of $3282 \mathrm{bp}$ is located on chromosome 10 and encodes a protein of 1094 amino acids with $45 \%$ similarity to Saccharomyces cerevisiae Pol $\delta[25,26]$. PfPol $\delta$ is expressed mainly in late trophozoite and schizont stages [27], but little is known about its enzymology and biochemical characteristics.

This study describes the cloning and expression of PfPol $\delta$ catalytic subunit (PfPol $\delta$-cat) and the characterization of its activity in presence of its small subunit (PfPol $\delta S$ ) and proliferating cell nuclear antigen (PfPCNA). In addition, the in vitro inhibitory effects of 11 synthetic compounds on both recombinant PfPolס-cat and parasite growth were evaluated for their potential as antiplasmodial drugs.

\section{Methods}

\section{Parasites culture}

Plasmodium falciparum strain K1, a chloroquine- and pyrimethamine-resistant strain from Thailand [28] was cultivated in RPMI 1640 medium (Invitrogen ${ }^{\mathrm{TM}}, \mathrm{CA}$, USA) supplemented with $10 \%$ human serum and human red blood cell (RBC) at $37^{\circ} \mathrm{C}$ under an atmosphere of $5 \%$ $\mathrm{CO}_{2}$. Plasmodium falciparum cultures containing mostly trophozoite and schizont stages were harvested when parasitaemia was $>10 \%$ by centrifugation at $500 \times g$ for 10 min at $25^{\circ} \mathrm{C}$.

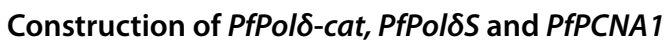 expression vectors}

Genomic DNA of $P$. falciparum strain $\mathrm{K} 1$ was used as

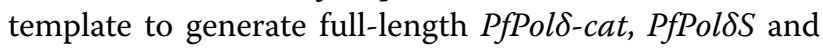
PfPCNA1. Amplification of PfPol $\delta$-cat was carried out using PfPol $\delta$-cat-forward (5'-CACCCATGGAAGAACT GAAAAC- $3^{\prime}$ ) and $P f$ Pol $\delta$-cat-reverse (5'-CCAATCCATT CTTAATGAGGT- $3^{\prime}$ ) primers and Phusion ${ }^{\circledR}$ High-Fidelity DNA polymerase (Thermo Scientific, MA, USA) together with 30 cycles of PCR consisting of $98^{\circ} \mathrm{C}$ for 1 min, $63{ }^{\circ} \mathrm{C}$ for $10 \mathrm{~s}$ and $72{ }^{\circ} \mathrm{C}$ for $105 \mathrm{~s}$. PfPolsS was amplified using PfPol $\delta S$-forward (5'-CACCATGGACGAAAAAGTAAC 
AAAC- $\left.3^{\prime}\right)$ and PfPol $\delta$ - $p 50$-reverse (5'-TTTGTCTTCGTC AATTTGAAAAGTC- $3^{\prime}$ ) primers and Platinum ${ }^{\circledR} P f x$ DNA polymerase $\left(\right.$ Invitrogen $^{\mathrm{TM}}$ ) together with 35 cycles of PCR consisting of $95^{\circ} \mathrm{C}$ for $1 \mathrm{~min}, 56^{\circ} \mathrm{C}$ for $40 \mathrm{~s}$ and $72{ }^{\circ} \mathrm{C}$ for 2 min. Pf-PCNA1 was amplified using primers previously described [29] and Phusion ${ }^{\circledR}$ High-Fidelity DNA polymerase together with 35 cycles of PCR consisting of $98{ }^{\circ} \mathrm{C}$ for $10 \mathrm{~min}, 58{ }^{\circ} \mathrm{C}$ for $5 \mathrm{~s}$ and $72{ }^{\circ} \mathrm{C}$ for $30 \mathrm{~s}$. Amplicons were analysed either by 0.8 or $1.5 \%$ agarose gel-electrophoresis. Amplified full-length PfPol $\delta$ cat and PfPolsS was cloned into pBAD202/D TOPO ${ }^{\circledR}$ and $\mathrm{pET101/D}$ TOPO $^{\circledR}$ expression vector (Invitrogen $^{\mathrm{TM}}$ ), respectively. The constructed vectors, pBAD-PfPol $\delta$-cat and $\mathrm{pET}$-PfPol $\delta \mathrm{S}$, were validated by nucleotide sequencing. Amplified full-length Pf-PCNA1 was cloned into $\mathrm{pQE}-30$ expression vector and named pQE-30-PfPCNA1.

\section{Expression and purification of PfPol $\delta$-cat, PfPol $\delta S$ and PfPCNA1}

pBAD-PfPol $\delta$-cat vector was transfected into $E$. coli LMG194 cells, which were grown in LB medium containing $50 \mu \mathrm{g} / \mathrm{ml}$ kanamycin at $37{ }^{\circ} \mathrm{C}$ with shaking until optical density of $600 \mathrm{~nm}$ reached 0.8 . Then cells were induced by an addition of $0.002 \%(\mathrm{w} / \mathrm{v}) \mathrm{L}$-arabinose and further incubated at $22{ }^{\circ} \mathrm{C}$ for $16-18 \mathrm{~h}$. Cells were sedimented at $4{ }^{\circ} \mathrm{C}$ and then re-suspended in 3.5 volumes of cold lysis buffer $(20 \mathrm{mM}$ Tris $-\mathrm{HCl} \mathrm{pH}$ 8.0 and $100 \mathrm{mM} \mathrm{NaCl}$ ) per g of bacterial pellet. Cells were lysed using XL 2020 Sonicator ${ }^{\circledR}$ Ultrasonic Processor XL (Heat System Inc., NY, USA), centrifuged at $10,000 \times g$ for $30 \mathrm{~min}$ at $4{ }^{\circ} \mathrm{C}$. Supernatant was incubated with Q Sepharose Fast Flow (GE Healthcare, UK) on ice for $10 \mathrm{~min}$ to remove bacterial DNA and then applied onto 1-ml HisTrap HP column (GE Healthcare) prior equilibration with buffer A $(20 \mathrm{mM}$ Tris- $\mathrm{HCl} \mathrm{pH}$ 8.0, $300 \mathrm{mM} \mathrm{NaCl}$ ) containing $10 \mathrm{mM}$ imidazole. The column was washed with buffer A containing $50 \mathrm{mM}$ imidazole and enzyme was eluted with $250 \mathrm{mM}$ imidazole-containing buffer A. Protein purity was analysed by SDS-PAGE.

pET-PfPolסS vector was used to transform E. coli BL21 (DE3) cells, which were grown in LB media containing $100 \mu \mathrm{g} / \mathrm{ml}$ ampicillin, and induced with $0.25 \mathrm{mM}$ isopropyl $\beta$-D-1-thiogalactopyranoside (IPTG) at $22{ }^{\circ} \mathrm{C}$ for $16 \mathrm{~h}$ with shaking. Cells were collected and lysed as described previously. Supernatant was applied onto 1-ml HisTrap HP column and recombinant PfPolסS was eluted using a linear gradient of $20-250 \mathrm{mM}$ imidazole in buffer A. Fractions of $0.25 \mathrm{ml}$ were collected and analysed by SDS-PAGE.

pQE-30-PfPCNA1 was transfected into JM109 E. coli cells, which were grown in LB medium, induced with $1 \mathrm{mM}$ IPTG at $25{ }^{\circ} \mathrm{C}$ for $16 \mathrm{~h}$, collected and lysed as described above. Supernatant was incubated with $\mathrm{Ni}-$ NTA agarose affinity beads (QIAGEN, Hilden, Germany) at $4{ }^{\circ} \mathrm{C}$ for $2 \mathrm{~h}$. The sample then was applied onto a gravity column, washed and protein eluted. The flow-through, wash and eluted fractions were collected, and analysed by SDS-PAGE. Protein concentrations were measured using Bradford assay [30] with bovine serum albumin (BSA) as standard.

\section{Western blotting and LC-MS/MS}

After SDS-PAGE, proteins were electro-transferred onto Hybond-P PVDF membrane (GE Healthcare) and incubated at $4{ }^{\circ} \mathrm{C}$ overnight in phosphate-buffered saline (PBS) containing $5 \%$ skim milk (blocking buffer). After washing three times with $0.05 \%$ Tween-20 PBS buffer, membrane was incubated with mouse anti-His antibodies (Invitrogen) at 1:5000 dilution in blocking buffer at room temperature for $2 \mathrm{~h}$. After washing, membrane was incubated with horseradish peroxidaseconjugated goat anti-mouse IgG for $1.5 \mathrm{~h}$ at room temperature and immunoreactive bands visualized using SuperSignal $^{\mathrm{TM}}$ West Pico Chemiluminescent Substrate (Thermo Scientific). The expected protein bands were excised from gels and digested with trypsin. Patterns of peptide fragments and amino acid sequences were analysed using LC-MS/MS equipped with MASCOT software.

\section{DNA polymerase assay}

DNA polymerase activity was assayed using activated calf thymus DNA (CT-DNA) (Sigma-Aldrich, MA, USA) as substrate. DNA polymerase assay was conducted in a $50-\mu \mathrm{l}$ reaction mixture containing $10 \mu \mathrm{g}$ of activated CT-DNA, $20 \mathrm{mM}$ potassium phosphate buffer $\mathrm{pH} 8,10 \mathrm{mM} \mathrm{MgCl}_{2}, 2 \mathrm{mM}$ DTT, $10 \mu \mathrm{g}$ BSA, $50 \mu \mathrm{M}$ each of dGTP, dATP and dCTP, $1 \mu \mathrm{M}$ dTTP, $2.5 \mu \mathrm{M}\left[\alpha{ }^{32} \mathrm{P}\right] \mathrm{dTTP}(800 \mathrm{Ci} / \mathrm{mmol}$; PerkinElmer, MA, USA), and $42 \mathrm{nM}$ PfPol $\delta$-cat. After incubation for $1 \mathrm{~h}$ at $37{ }^{\circ} \mathrm{C}$, the reactions were terminated by adding a $250-\mu \mathrm{l}$ mixture of $20 \mathrm{mM}$ EDTA, $0.1 \mathrm{mg} / \mathrm{ml} \mathrm{BSA}$ and $100 \mu \mathrm{l}$ of $50 \%$ trichloroacetic acid (TCA), followed by sedimentation. The precipitate was then washed twice with $1 \%$ TCA and $\left[{ }^{32} \mathrm{P}\right] \mathrm{dTMP}$ incorporation was measured in a 1450 MicroBeta ${ }^{\circledR}$ Trilux Liquid Scintillation Counter (Perkin Elmer). One unit of DNA polymerase activity is defined as the amount of enzyme that catalyzes the incorporation of $1 \mathrm{nmol}$ of dTMP into DNA in $1 \mathrm{~h}$ at $37^{\circ} \mathrm{C}$.

\section{Effects of divalent ions and $\mathrm{KCl}$ on PfPol $\delta$-cat activity}

The effects of divalent cations, $\mathrm{Mg}^{2+}$ and $\mathrm{Mn}^{2+}$, on PfPol $\delta$-cat activity were determined in the presence of $0.3 \mu \mathrm{M}$ PfPol $\delta$-cat and $0-50 \mathrm{mM} \mathrm{MgCl}{ }_{2}$ or $\mathrm{MnCl}_{2}$ in the 
polymerase assay. The effect of $\mathrm{KCl}$ was determined over the range $0-400 \mathrm{mM}$.

\section{$3^{\prime}-5^{\prime}$ exonuclease assay}

The $3^{\prime}-5^{\prime}$ exonuclease activity of PfPol $\delta$-cat was measured from the release of $\left[\alpha{ }^{32} \mathrm{P}\right] \mathrm{dTMP}$ from $3^{\prime}$ labelled poly(dA.dT) [16]. Substrate was prepared by incubating $125 \mu \mathrm{g} / \mathrm{ml}$ poly(dA.dT) with $5000 \mathrm{U} / \mathrm{ml}$ Klenow enzyme (New England Biolabs, MA, USA), $10 \mu \mathrm{M}\left[\alpha{ }^{32} \mathrm{P}\right] \mathrm{dTTP}$ in $50 \mathrm{mM}$ potassium phosphate $\mathrm{pH} 7.5,5 \mathrm{mM} \mathrm{MgCl}_{2}$, $1 \mathrm{mM}$ dAMP, and $0.5 \mathrm{mM} \beta$-mercaptoethanol. After incubation for $20 \mathrm{~min}$ at $37^{\circ} \mathrm{C}$, the reaction was termination by an addition of $10 \mathrm{mM}$ EDTA and $1 \mathrm{M} \mathrm{NaCl}$. The mixture was heated at $65^{\circ} \mathrm{C}$ for $30 \mathrm{~min}$ and unincorporated $\left[\alpha{ }^{32} \mathrm{P}\right] \mathrm{dTTP}$ removed employing AutoSeq ${ }^{\mathrm{TM}}$ G-50 dye terminator removal kit (GE Healthcare). For detection of exonuclease activity, a $30-\mu$ l reaction mixture containing $50 \mathrm{mM}$ HEPES $\mathrm{pH} 7.0,40 \mu \mathrm{g} / \mathrm{ml} \mathrm{BSA}, 10 \%$ glycerol, $2 \mathrm{mM} \mathrm{MgCl}, 1.25 \mu \mathrm{g}$ of $3^{\prime}$-labelled poly(dA.dT), and $0.2 \mu \mathrm{M}$ PfPol $\delta$-cat was incubated for $20 \mathrm{~min}$ at $37^{\circ} \mathrm{C}$ and radioactivity measured as described above.

\section{Processivity assay}

Processivity of PfPol $\delta$-cat was determined using $500 \mathrm{ng}$ of $(\mathrm{dA})_{1500} .(\mathrm{dT})_{12}$ (50:1 nucleotide ratio) as templateprimer. The $\mathrm{dT}_{12}$ primer was at $5^{\prime}$ labelled with $\left[\gamma^{-}{ }^{32} \mathrm{P}\right]$ dATP using T4 polynucleotide kinase and annealed to poly $(\mathrm{dA})_{1500}$. Reaction mixture consisting of $20 \mathrm{mM}$ Tris- $\mathrm{HCl} \mathrm{pH} 9.0,10 \mathrm{mM} \mathrm{MgCl}, 0.2 \mathrm{mg} / \mathrm{ml} \mathrm{BSA}, 2 \mathrm{mM}$ DTT, $50 \mu \mathrm{M}$ dTTP, and $42 \mathrm{nM}$ PfPol $\delta$-cat was incubated at $37{ }^{\circ} \mathrm{C}$ for $30 \mathrm{~min}$. The product was precipitated with ethanol, dried, dissolved in sample buffer (95\% deionized formamide, $25 \mathrm{mM}$ EDTA and $0.01 \%$ bromophenol) and electrophoresed in $8 \%$ polyacrylamide gel containing $7 \mathrm{M}$ urea. Gel was exposed overnight to X-ray film at $-80{ }^{\circ} \mathrm{C}$.

\section{Effects of PfPol $\delta$ S and PfPCNA1 on PfPol $\delta$-cat activity}

PfPol $\delta \mathrm{S}(0-1 \mu \mathrm{M})$ was added to a standard DNA polymerase assay containing $0.15 \mu \mathrm{g}$ of polydA.oligodT and $1 \mu \mathrm{M}$ PfPCNA1 and incubated at $37{ }^{\circ} \mathrm{C}$ for $30 \mathrm{~min}$. The reaction mixtures were processed as described.

\section{Inhibitory effects of synthetic compounds on PfPol $\delta$-cat activity}

Inhibitory activity of 11 compounds consisting of substrate and nucleotide analogs and potential active site occupiers of PfPol $\delta$-cat were compared with known Pol $\delta$ inhibitors, aphidicolin and N-ethylmaleimide (NEM). Stock solution $(6 \mathrm{mM})$ of aphidicolin was prepared in dimethylsulfoxide (DMSO) and that of NEM $(400 \mathrm{mM})$ in absolute ethanol. Stock solutions $(10 \mathrm{mM})$ of $N^{2}$-(4-butylphenyl)-2'-deoxyguanosine $5^{\prime}$-triphosphate
(BuPdGTP), $\quad N^{2}$-(4-butylphenyl)- $\quad 2^{\prime}$-deoxyguanosine $5^{\prime}$-( $P^{2}, P^{3}$-carbonyltriphosphonate) (BuPdGMPPCOP), $N^{2}$ ethyl-2'-deoxyguanosine $5^{\prime}$-triphosphonate (EtdGTP), $N^{2}$ hexyl-2'-deoxyguanosine $5^{\prime}$-triphosphate (HexdGTP) and Acyclovir triphosphate (ACV-TP) were prepared in sterile distilled water, while those of 2-amino-4-chloro-6-(3,4dichloroanilino)pyrimidine, 2-amino-4-chloro-6-(3,5dichloroanilino)pyrimidine, $\quad \mathrm{N}^{2}$-(3,4-dichlorobenzyl) guanine (DCBG), $\mathrm{N}^{2}$-(3-fluoro,4-chlorobenzyl)guanine, 3-(4-hydroxybutyl)-6-(3-ethyl-4-methylanilino)uracil (HB-EMAU), and 7-acetoxypentyl-(3,4-dichlorobenzyl) guanine (7-acetoxypentyl-DCBG) were prepared in DMSO. All stock solutions were stored at $-20{ }^{\circ} \mathrm{C}$ until used. Test concentrations of compounds were prepared by diluting stock solution with $10 \mathrm{mM}$ Tris- $\mathrm{HCl} \mathrm{pH}$ 8.0 and evaluated in triplicate. Compounds were added directly to the reaction mixtures except for NEM that was pre-incubated with enzyme for $30 \mathrm{~min}$ on ice before addition to the reaction mixture. Polymerase activity assays were conducted as described above.

\section{Inhibition of intra-erythrocytic $P$. falciparum growth in culture}

Plasmodium falciparum K1 strain was synchronized at ring stage using $5 \% \mathrm{D}$-sorbitol treatment and then mixed with culture medium containing RPMI 1640 medium supplement with $10 \%$ human serum. Twofold serial dilutions of each test compound were evaluated in triplicate. Parasite growth was determined by a SYBR Green I-based assay [31, 32]. Dose-response curves and $\mathrm{IC}_{50}$ values were obtained using SigmaPlot 12.0.

\section{Results}

Expression and purification of recombinant PfPolס-cat, PfPolסS and PfPCNA1

The 3285-bp full-length PfPol $\delta$-cat of P. falciparum K1 strain was successfully amplified and cloned employing pBAD202/D TOPO $^{\circledR}$ expression vector. Its nucleotide sequence showed $99 \%$ identity to that of $P$. falciparum 3D7 (NCBI reference sequence XM_001347414.1). The deduced amino acid sequence (1094 amino acids) of PfPol $\delta$-cat is 84 and $59.2 \%$ similar to that of Plasmodium vivax and humans, respectively (Table 1 ).

Recombinant PfPol $\delta$-cat was expressed as thioredoxinPfPol $\delta$-cat-His $_{6}$ fusion protein in Escherichia coli LMG194 and purified by $\mathrm{Ni}^{2+}$ affinity chromatography, having the expected size of $143 \mathrm{kDa}$. The method yielded $0.48 \mathrm{mg}$ of protein/l culture. Western blot analysis using His-specific antibody indicated a single PfPol $\delta$-cat band of the expected $143 \mathrm{kDa}$ (Fig. 1). After excision from gel, trypsin digestion and amino acid sequence analysis using LC-MS/MS, seven peptides were obtained that matched the sequence of $P$. falciparum 3D7 Pol $\delta$-cat with ion 
Table 1 Amino acid sequence similarity of PfPolס-cat compared with Polठ from other organisms

\begin{tabular}{lll}
\hline Organism & $\begin{array}{l}\text { Accession number } \\
\text { of NCBI protein } \\
\text { reference sequence }\end{array}$ & Similarity (\%) \\
\hline P. falciparum 3D7 & XP_001347450.1 & 100 \\
Plasmodium vivax Sal-1 & XP_001612703.1 & 84.0 \\
Homo sapiens & NP_001243778.1 & 59.2 \\
Schizosaccharomycespombe & NP_596124.1 & 62.4 \\
S. cerevisiae S288C & NP_010181.2 & 59.4 \\
Toxoplasmagondii & XP_002365027.1 & 57.0 \\
Mus musculus & NP_035261.3 & 60.4 \\
\hline
\end{tabular}

scores of 100, indicating identity or extensive homology ( $p$ value $<0.05)$.

In addition to PfPol $\delta$-cat, PfPol $\delta S$ and PfPCNA1 were expressed and purified. PfPolסS was expressed under the regulation of $\mathrm{T} 7$ promoter and carried $\mathrm{His}_{6}$ at $\mathrm{C}$-terminus. Affinity purified PfPol $\delta S$ with a molecular mass of $57 \mathrm{kDa}$ was obtained (Fig. 2), and its identity was confirmed by LC-MS/MS, which yielded five peptides matching $P$. falciparum 3D7 DNA polymerase $\delta$ small subunit with ion scores of 168. The deduce amino acid sequence of PfPol $\delta S$ reveals 49.1 and $24.7 \%$ similarity with that of $P$. vivax and

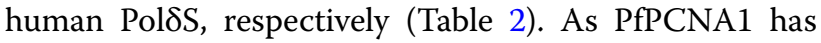
been characterized previously [27], the reported protocols were adapted to obtain a purified protein of $34 \mathrm{kDa}$ with final yield of $4.35 \mathrm{mg} / \mathrm{l}$ culture (Fig. 3).

\section{Biochemical characterization of PfPol $\delta$-cat}

Recombinant PfPol $\delta$-cat exhibited both DNA polymerase (Fig. 4) and $3^{\prime}-5^{\prime}$ exonuclease activity, the latter property being based on the release of $\left[\alpha-{ }^{32} \mathrm{P}\right] \mathrm{dTMP}$ from $3^{\prime}$-labelled-poly(dA.dT), reducing TCA insoluble material by $96.6 \pm 1.2 \%$ after $20 \mathrm{~min}$ incubation at $37{ }^{\circ} \mathrm{C}$. PfPol $\delta$-cat polymerase activity required presence of divalent metal ions, $\mathrm{Mn}^{2+}$ or $\mathrm{Mg}^{2+}$, with maximal polymerase activity being achieved at 2.5 and $5 \mathrm{mM}$ respectively (Fig. 4a). Although both divalent cations activated polymerase activity, PfPol $\delta$-cat was approximately threefold more active in the presence of $\mathrm{Mg}^{2+}$ than $\mathrm{Mn}^{2+}$ at their respective optimal concentration. As regards $\mathrm{KCl}$ requirement, PfPol $\delta$-cat showed maximal polymerase activity at $100 \mathrm{mM} \mathrm{KCl}$ and activity decreased when $\mathrm{KCl}$ was $>200 \mathrm{mM}$ (Fig. 4b).

\section{Effects of PfPolסS and PfPCNA1 on PfPol $\delta$-cat polymerase activity}

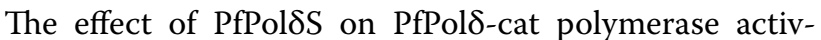
ity was determined by adding recombinant PfPol $\delta S$ to a standard polymerase assay in the presence or absence of PfPCNA1. PfPol $\delta S$ was able to stimulate PfPol $\delta$-cat DNA polymerase activity threefold, which was abrogated in the presence of heat-treated PfPolסS (Fig. 5). However, the presence of PfPCNA1 alone did not alter PfPol $\delta$-cat polymerase activity, but there was a fourfold increase in activity was when both PfPoldS and PfPCNA1 were present (Fig. 6).

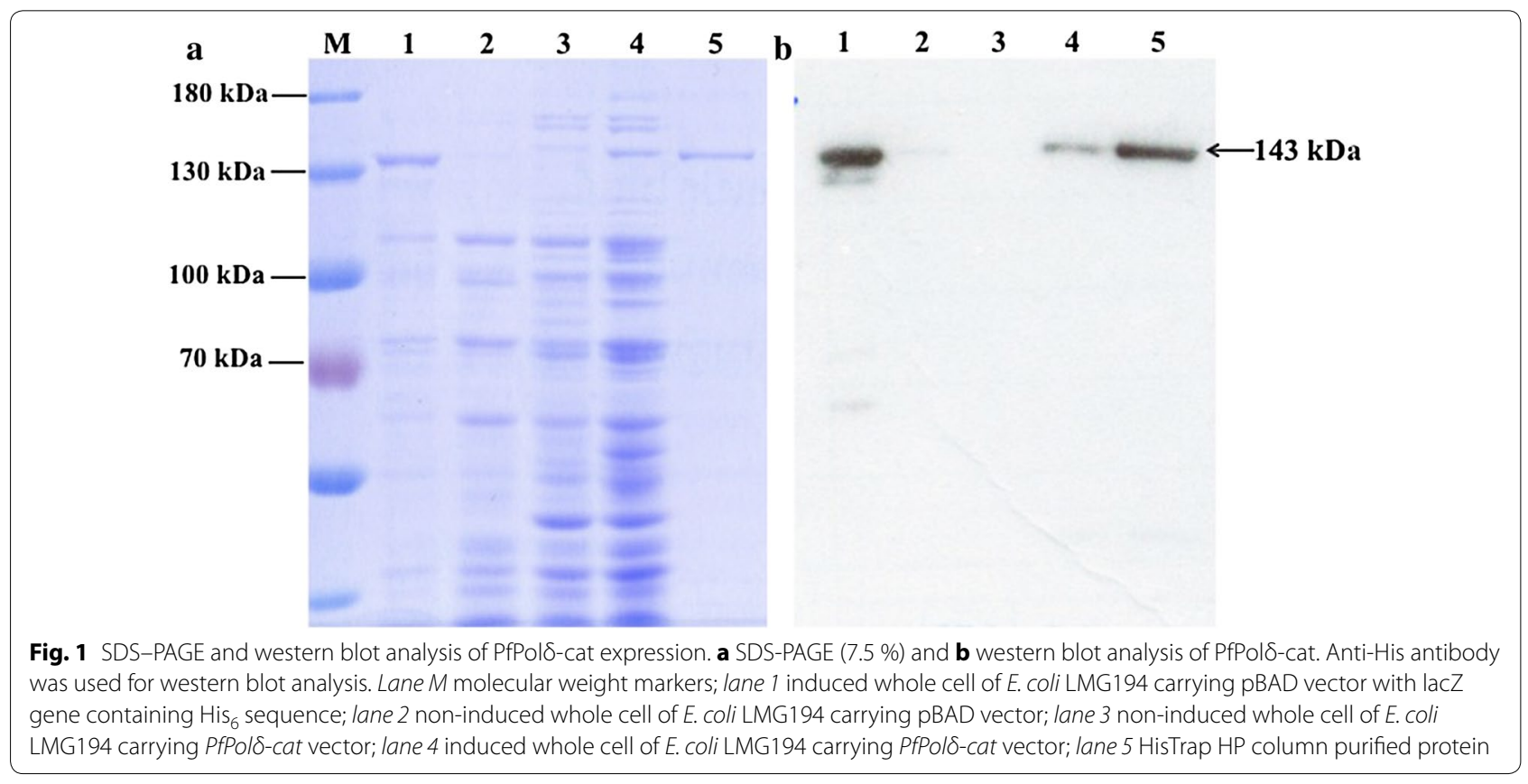




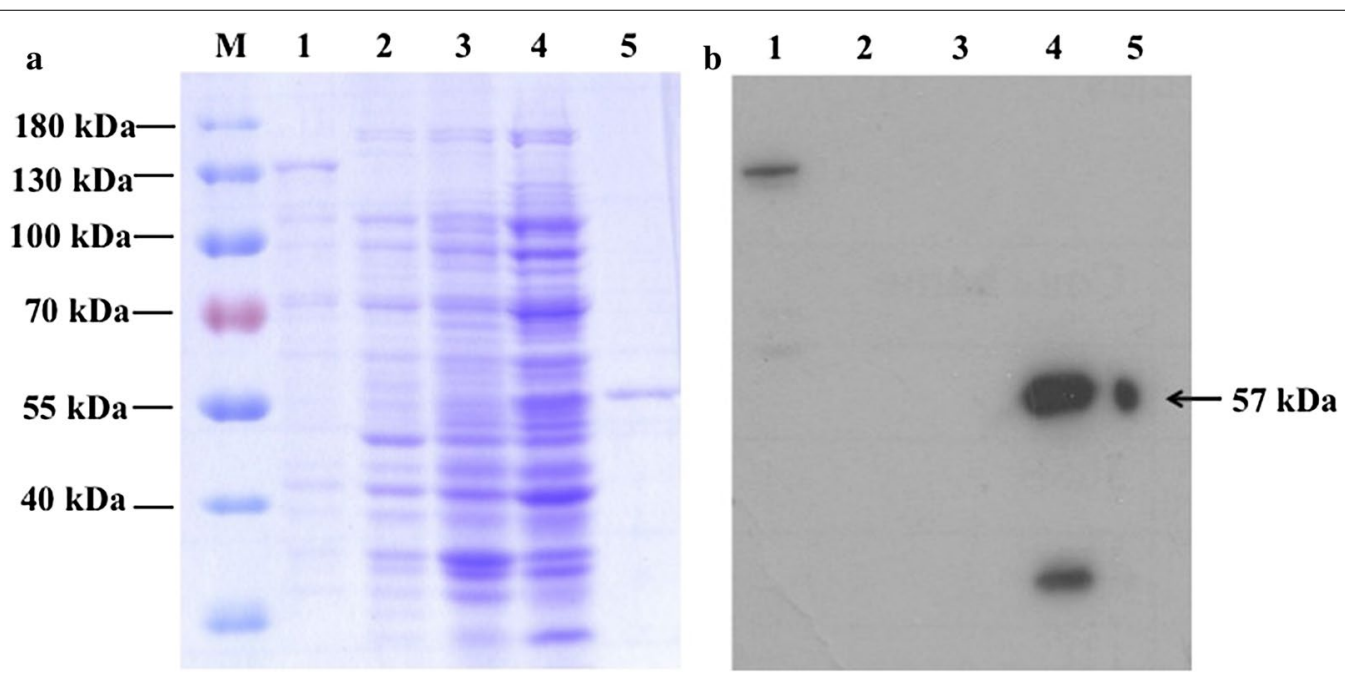

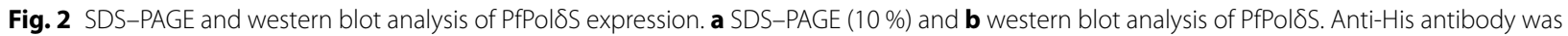
used for western blot analysis. Lane M molecular weight markers; lane 1 positive control vector with lacZ gene containing His ${ }_{6}$ sequence; lane 2 noninduced whole cell of E. coli BL21 carrying pET vector; lane 3 non-induced whole cell of E. coli BL21 carrying PfPol $\delta S$ vector; lane 4 induced whole cell of E. coli BL21 carrying PfPolઠS vector; lane 5 HisTrap HP column purified protein

Table 2 Amino acid sequence similarity of PfPolסS compared with other organisms

\begin{tabular}{llll}
\hline No. & Organism & $\begin{array}{l}\text { GenBank } \\
\text { accession no. }\end{array}$ & Similarity (\%) \\
\hline 1 & P. falciparum 3D7 & CAB11105.1 & 85.9 \\
2 & P. vivax & EDL43374.1 & 49.1 \\
3 & P. knowlesi strain H & CAQ39738.1 & 51.4 \\
4 & H. sapiens & AAC50216.1 & 24.7 \\
5 & S. pombe & CAB11679.1 & 19.4 \\
6 & Entamoeba dispar & EDR22929.1 & 16.9 \\
7 & Candida dubliniensis CD36 & CAX41815.1 & 18.7 \\
8 & Culex quinquefasciatus & EDS33455.1 & 24.0 \\
\hline
\end{tabular}

\section{Processivity of PfPol $\delta$-cat}

PfPol $\delta$-cat processivity was investigated using $(\mathrm{dA})_{1500}$. $(\mathrm{dT})_{12}$ as substrate in comparison with that of $E$. coli DNA polymerase Klenow fragment. In the presence of

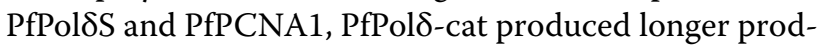
ucts (higher processivity) than in their absence (Fig. 7).

\section{Effects of inhibitors on DNA polymerase activity of PfPolס-cat and parasite growth}

Of the 11 synthetic compounds tested on PfPol $\delta$ polymerase activity only four showed inhibitory effects, namely, BuPdGTP $\left(\mathrm{IC}_{50}=38 \mu \mathrm{M}\right)$, 7-acetoxypentyl-DCBG $\left(\mathrm{IC}_{50}=55 \mu \mathrm{M}\right), 2$-amino-4-chloro-6-(3', $4^{\prime}$-dichloroanilino) pyrimidine $\left(\mathrm{IC}_{50}=104 \mu \mathrm{M}\right)$ and 2-amino-4-chloro-6-( $3^{\prime}$, 5'-dichloroanilino)pyrimidine $\left(\mathrm{IC}_{50}=185 \mu \mathrm{M}\right)$, but still less potent than aphidicolin $\left(\mathrm{IC}_{50}=11.8 \mu \mathrm{M}\right)$ and NEM
$\left(\mathrm{IC}_{50}=8.6 \mathrm{mM}\right)$, as seen with other eukaryotic Pol $\delta$ [14-16] (Table 3). These four compounds also inhibited $P$. falciparum $\mathrm{K} 1$ strain growth in culture, with $\mathrm{IC}_{50}$ values ranging from 3.8 to $85.6 \mu \mathrm{M}$ (Table 3). However, DCBG, $\mathrm{N}^{2}$-(3-fluoro,4-chlorobenzyl)guanine and HB-EMAU exhibited inhibitory effects on $P$. falciparum growth, with $\mathrm{IC}_{50}$ values of 8.8, 7.4 and $10.2 \mu \mathrm{M}$, respectively.

\section{Discussion}

Since 1976, when, for the first time, Pol $\delta$ was described in bone marrow as a novel DNA polymerase possessing a $3^{\prime}-5^{\prime}$ proofreading exonuclease activity [33], eukaryotic Pol $\delta$ s have been purified and characterized from several organisms [16, 17, 34], with the exception of malarial parasites.

PfPol $\delta$ partially purified from parasite crude extract using Hitrap Capto Q and Hitrap Heparin columns in a fast protein liquid chromatography (FPLC) system exhibited $3^{\prime}-5^{\prime}$ exonuclease activity and was sensitive to aphidicolin and NEM (unpublished). However, possible co-purification of PfPole could not be rule out. Subsequent purification of PfPol $\delta$ to near homogeneity was hampered by very low recovery yield and a lack of Pol $\delta$-specific affinity column able to separate it from PfPole. Therefore, in this study a DNA recombinant approach was used to study PfPol $\delta$ catalytic subunit, in the presence of its small subunit PfPol $\delta S$ and PfPCNA. Moreover, recombinant techniques provided sufficient amounts of enzyme to allow testing as a potential anti-malarial drug target. 


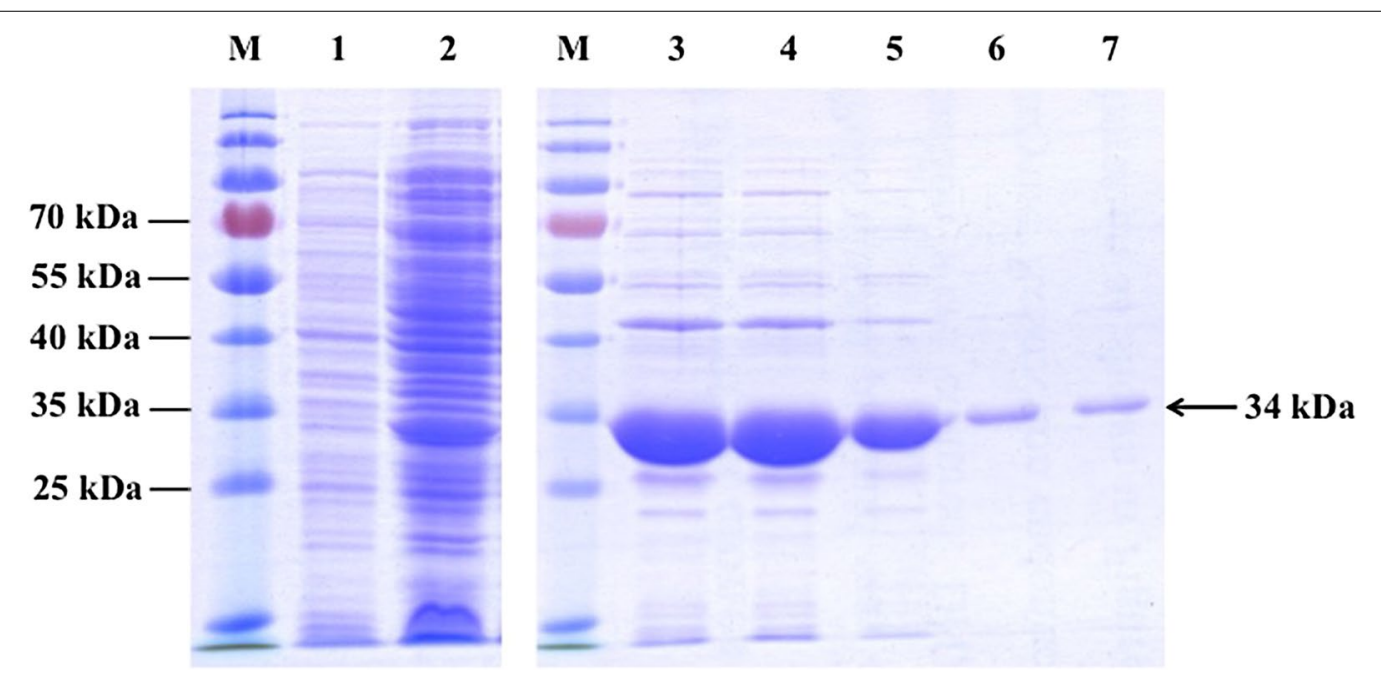

Fig. 3 Analysis of recombinant PfPCNA1 expression by $12 \%$ SDS-PAGE. Gel was stained with Coomassie blue R250. Lane M molecular weight markers; lane 1 non-induced whole cells of E. coli JM109 expression host; lane 2 total soluble protein from 1 mM IPTG-induced E. coli JM109 carrying PfPCNA1-constructed vector; lanes 3-7 elution fractions from Ni-NTA agarose purified protein

Recombinant PfPol $\delta$ was successfully cloned and heterologously expressed in $E$. coli, but the expressed protein was produced in an insoluble form at $37^{\circ} \mathrm{C}$. The expression condition was optimized by reducing expression temperature, which usually increases soluble protein yield [35]. The size of expressed PfPol $\delta$-cat was $126 \mathrm{kDa}$, comparable to $130 \mathrm{kDa}$ of E. coli Pol III [36] and $125 \mathrm{kDa}$ of purified human enzyme [16]. Tandem mass spectrometry of trypsinized recombinant PfPol $\delta$ revealed seven peptides that showed high homology with the sequence of DNA polymerase $\delta$ catalytic subunit of $P$. falciparum strain 3D7. Characterization of recombinant PfPol $\delta$-cat showed that it possesses both DNA polymerase activity and $3^{\prime}-5^{\prime}$ exonuclease activity, as found in other mammalian Polסs [16, 17, 34].

PCNA functions as a processivity factor for Pol $\delta$ by forming a molecular sliding clamp and also plays a crucial role in DNA transactions where it acts as a scaffold for the recruitment and organization of protein complexes involved in both DNA replication and repair [19]. A previous study of protein-protein interactions of human Pol $\delta$-PCNA complex suggested that the interaction between Pol $\delta$ and PCNA likely happens through multiple contacts via its four subunits, p12, p50, p68, and p125 [19, 37]. In this study, PfPol $\delta$-cat polymerase activity was stimulated threefolds with the addition of PfPol $\delta S$ and fourfolds in the presence of both PfPolסS and PfPCNA. The magnitude of malarial enzyme activity stimulation is comparable to those obtained from examination of the effect of human recombinant p50 on the activity of DNA polymerase $\delta$, showing that p50 is able to slightly stimulate (about twofold) the activity of the recombinant
$125 \mathrm{kDa}$ catalytic subunit in the absence of PCNA, while in the presence of PCNA polymerase activity is stimulated about fivefold [38]. In addition, a combination of PfPol $\delta$-cat, PfPol $\delta S$ and PfPCNA1 demonstrated highest processivity compared with individual protein or incomplete combination. These findings are consistent with previous report indicating that small subunit p50 is required for mediation of the interaction of human Pol $\delta$ catalytic subunit (p125) with PCNA [19]. In this study, replication factor C (RFC) or clamp loader of P. falciparum was not used in the assay with PfPolS and PCNA, and thus higher activity of PfPol $\delta$-cat would be expected upon addition of RFC as the latter is responsible for loading PCNA onto DNA during DNA replication [6]. In addition to its important function in DNA replication, a role of PfPolס-cat in base excision repair should be investigated when additional enzymes or proteins in parasite BER pathway become available.

All DNA polymerases use the same two metal cations (usually $\mathrm{Mg}^{2+}$ ) as co-factors for dNTP polymerization. In this study, PfPol $\delta$-cat was able to use both $\mathrm{Mg}^{2+}$ and $\mathrm{Mn}^{2+}$ and could be activated by $5 \mathrm{mM} \mathrm{Mg}^{2+}$ as found for both human and calf thymus Pol $\delta[16,17]$. However, in the case of $\mathrm{Mn}^{2+}$, optimal concentration $(2.5 \mathrm{mM})$ required by the parasite enzyme was five- to eightfold higher than that optimal for human and calf thymus Pol $\delta$ (0.3-0.5 mM) [39].

PfPol $\delta$ activity was differently affected by salt concentrations compared with calf thymus and human recombinant enzymes. The maximal polymerase activity of PfPold-cat was at $100 \mathrm{mM} \mathrm{KCl}$ and declined at higher concentrations $(>200 \mathrm{mM})$. These findings are different from those 

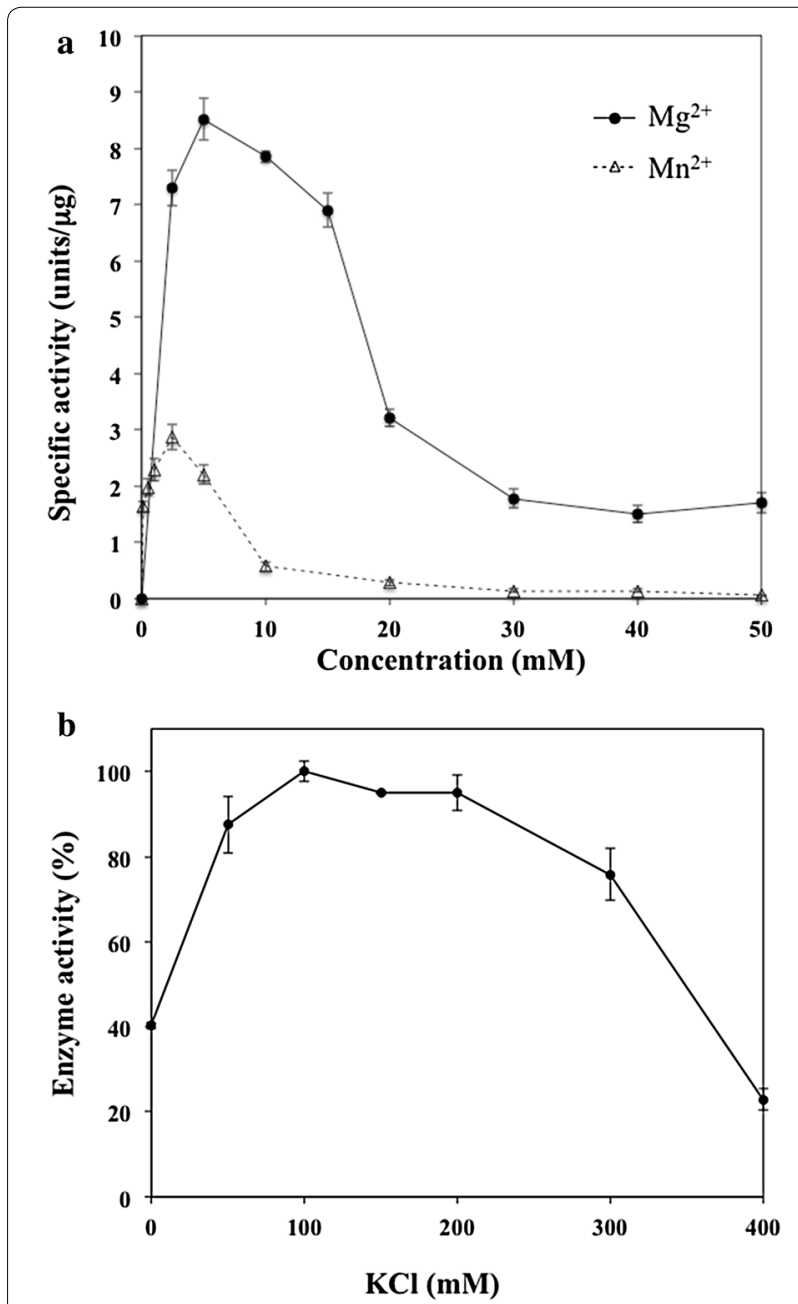

Fig. 4 Effects of divalent cation cofactors and $\mathrm{KCl}$ concentrations on PfPol $\delta$-cat. DNA polymerase activity of PfPol $\delta$-cat was determined using CT-DNA as template-primer. a PfPol $\delta$-cat activities were investigated in the presence of $\mathrm{MgCl}_{2}$ (circle) and $\mathrm{MnCl}_{2}$ (triangle) and presented as specific activity. $\mathbf{b}$ concentrations of $\mathrm{KCl}$ were varied as indicated. Maximal activity of enzyme is designated as $100 \%$. Data are shown as mean \pm SD

observed with recombinant human and calf thymus Pol $\delta$, where only 50 and $38 \%$ of enzyme activity respectively was found at $50 \mathrm{mM} \mathrm{KCl}[16,39]$. Unlike the human and calf thymus enzymes, Pol $\delta$ of Drosophila is slightly stimulated by low $\mathrm{KCl}$ concentration $(25 \mathrm{mM})$ [40]. Recombinant Pol3 of Schizosaccharomyces pombe shows maximal activity at $240 \mathrm{mM} \mathrm{KCl}$, whereas its native form is sensitive to high salt concentration [41]. It is possible that $\mathrm{KCl}$ may help stabilize protein at a concentration suitable for function or to reduce its self-aggregation.

Only 4 of 11 synthetic compounds showed inhibitory effects on PfPol $\delta$-cat activity when compared with known
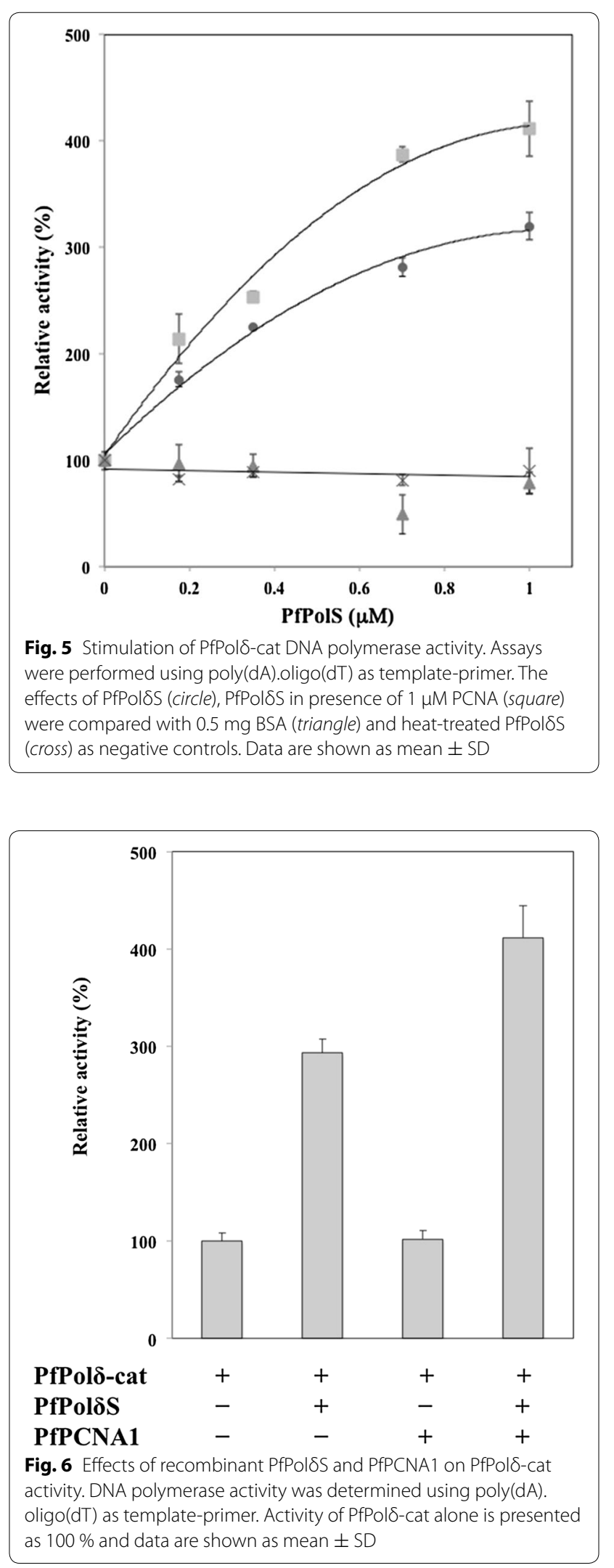


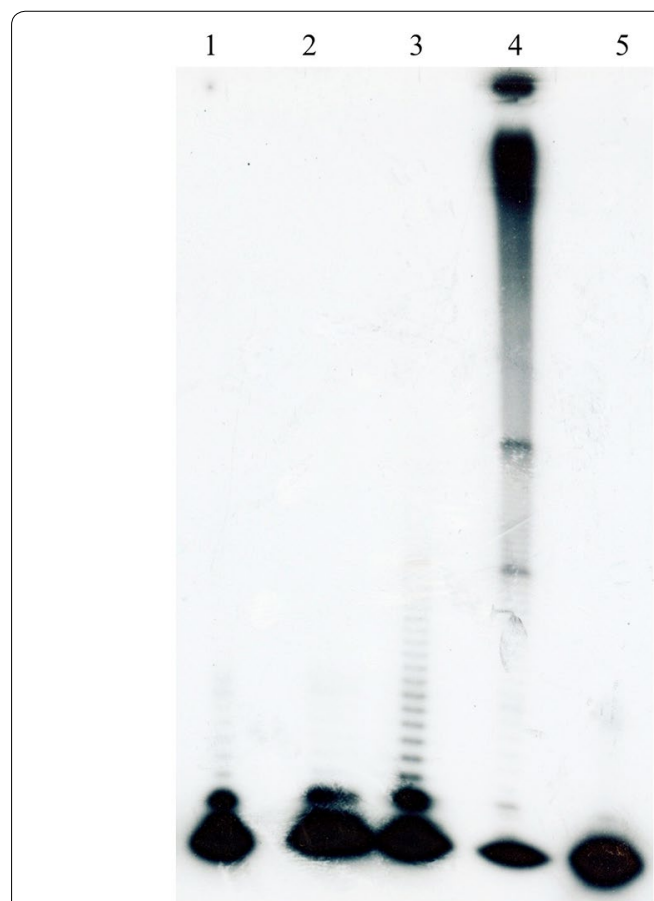

Fig. 7 Effects of PfPol $\delta S$ and PfPCNA1 on processivity of PfPol $\delta$-cat. Lane 1 products of PfPol $\delta$-cat; lane 2 products of PfPol $\delta$-cat in the presence of PfPol $\delta$; lane 3 PfPol $\delta$-cat in the presence of PfPol $\delta S$ and PfPCNA1; lane 4 products of E.coli Klenow enzyme as positive control; lane 5 negative control

Table 3 Inhibitory effects $\left(\mathrm{IC}_{50}\right)$ of compounds on PfPolסcat activity and in vitro malaria parasite growth

\begin{tabular}{|c|c|c|}
\hline \multirow[t]{2}{*}{ Compound } & \multicolumn{2}{|l|}{$\mathrm{I} C_{50}(\mu \mathrm{M})$} \\
\hline & PfPolס-cat & P. falciparum \\
\hline BuPdGTP & $38.0 \pm 1.7$ & $85.6 \pm 3.7$ \\
\hline 7-acetoxypentyl-DCBG & $55.0 \pm 3.4$ & $4.1 \pm 0.2$ \\
\hline $\begin{array}{l}\text { 2-amino-4-chloro-6-(3', } 4^{\prime} \text {-dichloroanilino) } \\
\text { pyrimidine }\end{array}$ & $104.0 \pm 5.6$ & $3.8 \pm 0.3$ \\
\hline $\begin{array}{l}\text { 2-amino-4-chloro-6-(3', 5'-dichloroanilino) } \\
\text { pyrimidine }\end{array}$ & $185.0 \pm 7.7$ & $34.4 \pm 0.4$ \\
\hline BuPdGMPPCOP & Inactive $^{a}$ & $173.4 \pm 2.7$ \\
\hline EtdGTP & Inactive $^{\mathrm{a}}$ & $157.8 \pm 3.4$ \\
\hline HexdGTP & Inactive $^{\mathrm{a}}$ & $86.4 \pm 0.2$ \\
\hline Acyclovir triphosphate & Inactive ${ }^{a}$ & $347.2 \pm 8.3$ \\
\hline DCBG & Inactive ${ }^{a}$ & $8.8 \pm 0.5$ \\
\hline $\mathrm{N}^{2}$-(3-fluoro,4-chlorobenzyl)guanine & Inactive $^{a}$ & $7.4 \pm 0.3$ \\
\hline HB-EMAU & Inactive ${ }^{a}$ & $10.2 \pm 0.4$ \\
\hline
\end{tabular}

a $<20 \%$ inhibition at $100 \mu \mathrm{M}$

DNA polymerase inhibitors such as aphidicolin and NEM. The most potent inhibitor of PfPolס-cat was BuPdGTP, which strongly inhibited mammalian Pol $\alpha$ compared with Pol $\delta$ and $\varepsilon$ [42]. In contrast to BuPdGTP, 2-amino4-chloro-6-(3',4'-dichloroanilino)pyrimidine showed low inhibitory effect on PfPol $\delta$-cat but was the most potent inhibitor of parasite growth in culture. Inhibition of PfPolסcat activity by these two compounds did not directly correlate with parasite growth inhibition, suggesting that they may have different cell permeability and metabolic properties. However, 7-acetoxypentyl-DCBG was the most potent inhibitor of both PfPol $\delta$-cat activity and parasite growth. Recently, 7-acetoxypentyl-DCBG was shown to be a potent antibiotic, showing an MIC of $1.25 \mu \mathrm{g} / \mathrm{ml}$ and a clear doseresponse effect ( $80 \%$ mice survived after treatment with an IP dose of $60 \mathrm{mg} / \mathrm{kg}$ ) [43]. Taken together, 7-acetoxypentylDCBG is a promising starting template for future rational design of a selective inhibitor against PfPol $\delta$ and may lead to development of novel anti-malarial agents.

\section{Conclusions}

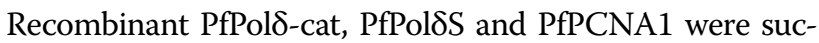
cessfully expressed heterologously. PfPol $\delta$-cat contains both DNA polymerase and $3^{\prime}-5^{\prime}$ exonuclease activity as found in the human counterpart. However, recombinant

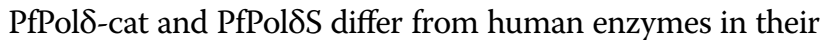
deduced amino acid sequences. A combination of PfPolS and PfPCNA clearly stimulated PfPol $\delta$-cat DNA polymerase activity and processivity. Recombinant PfPol $\delta$-cat was inhibited by two guanine analogs, namely, BuPdGTP and 7-acetoxypentyl-DCBG. Furthermore, 7-acetoxypentylDCBG was demonstrated to be a potent inhibitor of in vitro malaria parasite growth. Analogs of this compound should further be developed into more potent anti-malarial drugs.

\section{Authors' contributions}

JV performed most of the laboratory work and manuscript preparation. AM performed some laboratory work on the small subunit of the enzyme. SM, UL and SP participated in designing molecular work and editing the manuscript. FF was involved in study design of enzyme function, discussion and editing the manuscript. GEW performed compound synthesis and editing of the manuscript. PCP was involved in study design, data analysis, discussion and editing of the manuscript. All authors read and approved the final manuscript.

\section{Author details}

${ }^{1}$ Department of Protozoology, Faculty of Tropical Medicine, Mahidol University, 420/6 Rajvithi Road, Bangkok 10400, Thailand. ${ }^{2}$ National Centre for Genetic Engineering and Biotechnology, National Science and Technology Development Agency, 113 Thailand Science Park, Pahonyothin Rd, Pathumthani 12120, Thailand. ${ }^{3}$ Department of Molecular Tropical Medicine and Genetics, Faculty of Tropical Medicine, Mahidol University, Bangkok 10400, Thailand. ${ }^{4}$ Institute of Molecular Genetics, CNR, 27100 Pavia, Italy. ${ }^{5}$ GLSynthesis Inc., One Innovation Drive, Worcester, MA 01605, USA.

\section{Acknowledgements}

We thank Ms. Kanthinich Thima, Department of Protozoology, Faculty of Tropical Medicine, Mahidol University for technical assistance in parasite culture. This study was supported by the National Science and Technology Development Agency (NSTDA), Ministry of Science and Technology of Thailand (Grant no. BT-B-01-MG-14-5117). JV was recipient of a scholarship from the Royal Golden Jubilee (RGJ) Ph.D. program, The Thailand Research Fund (TRF) and Mahidol University (grant no. PHD/0167/2549).

\section{Competing interests}

The authors declare that they have no competing interests. 
Received: 14 October 2015 Accepted: 11 February 2016 Published online: 24 February 2016

\section{References}

1. WHO. World Malaria report 2014. Geneva: World Health Organization; 2014.

2. Dondorp AM, Nosten F, Yi P, Das D, Phyo AP, Tarning J, et al. Artemisinin resistance in Plasmodium falciparum malaria. N Engl J Med. 2009;361:455-67.

3. Phyo AP, Nkhoma S, Stepniewska K, Ashley EA, Nair S, McGready R, et al. Emergence of artemisinin-resistant malaria on the western border of Thailand: a longitudinal study. Lancet. 2012;379:1960-6.

4. Wongsrichanalai $\mathrm{C}$, Sibley $\mathrm{CH}$. Fighting drug-resistant Plasmodium falciparum: the challenge of artemisinin resistance. Clin Microbiol Infect. 2013;19:908-16.

5. Sutton MD, Walker GC. Managing DNA polymerases: coordinating DNA replication, DNA repair, and DNA recombination. Proc Natl Acad Sci USA 2001;17:8342-9.

6. Hübscher U, Maga G, Spadari S. Eukaryotic DNA polymerases. Annu Rev Biochem. 2002;71:133-63.

7. Stillman B. DNA polymerases at the replication fork in eukaryotes. Mol Cell. 2008;30:259-60.

8. McConnell M, Miller H, Mozzherin D, Quamina A, Tan CK, Downey KM, et al. The Mammalian DNA Polymerase $\delta$ - proliferating cell nuclear antigen-Template-primer complex: molecular characterization by direct binding. Biochemistry. 1996;35:8268-74.

9. Krishna TS, Kong XP, Gary S, Burgers PM, Kuriyan J. Crystal structure of the eukaryotic DNA polymerase processivity factor PCNA. Cell. 1994;79:1233-43.

10. Hakem R. DNA- damage repair; the good, the bad, and the ugly. EMBO J. 2008;27:589-605.

11. Haltiwanger BM, Matsumoto Y, Nicolas E, Dianov GL, Bohr VA, Taraschi TF. DNA base excision repair in human malaria parasites is predominately by a long-patch pathway. Biochemistry. 2000;39:763-72.

12. Gerik KJ, Li X, Pautz A, Burgers PM. Characterization of the two small subunits of Saccharomyces cerevisiae DNA polymerase delta. J Biol Chem. 1998;273:19747-55

13. Burgers PM, Gerik KJ. Structure and processivity of two forms of Saccharomyces cerevisiae DNA polymerase delta. J Biol Chem. 1998;273:19756-62.

14. Johansson E, Majka J, Burgers PM. Structure of DNA polymerase delta from Saccharomyces cerevisiae. J Biol Chem. 2001;276:43824-8.

15. Zuo S, Bermudez V, Zhang G, Kelman Z, Hurwitz J. Structure and activity associated with multiple forms of Schizosaccharomyces pombe DNA polymerase delta. J Biol Chem. 2000;275:5153-62.

16. Zhou JQ, Tan CK, So AG, Downey KM. Purification and characterization of the catalytic subunit of human DNA polymerase delta expressed in baculovirus-infected insect cells. J Biol Chem. 1996;271:29740-5.

17. Weiser T, Gassmann M, Thömmes P, Ferrari $E$, Hafkemeyer $P$, Hübscher U. Biochemical and functional comparison of DNA polymerases alpha, delta, and epsilon from calf thymus. J Biol Chem. 1991;266:10420-8.

18. Focher F, Spadari S, Ginelli B, Hottiger M, Gassmann M, Hübscher U. Calf thymus DNA polymerase delta: purification, biochemical and functional properties of the enzyme after its separation from DNA polymerase alpha, a DNA dependent ATPase and proliferating cell nuclear antigen. Nucleic Acids Res. 1988;16:6279-95.

19. Wang Y, Zhang Q, Chen H, Li X, Mai W, et al. P50, the small subunit of DNA polymerase delta, is required for mediation of the interaction of polymerase delta subassemblies with PCNA. PLoS One. 2011;6:e27092.

20. Hughes P, Tratner I, Ducoux M, Piard K, Baldacci G. Isolation and identification of the third subunit of mammalian DNA polymerase delta by PCNAaffinity chromatography of mouse FM3A cell extracts. Nucleic Acids Res. 1999:27:2108-14

21. Liu L, Mo J, Rodriguez-Belmonte EM, Lee MY. Identification of a fourth subunit of mammalian DNA polymerase delta. J Biol Chem. 2000;275:18739-44.

22. Chavalitshewinkoon P, De Vries E, Franssen FFJ, Overdulve JP, Van der Vliet PC. Purification and characterization of DNA polymerases from Plasmodium falciparum. Mol Biolchem Parasitol. 1993;61:243-54.
23. Nunthawarasilp P, Petmitr S, Chavalitshewinkoon-Petmitr P. Partial purification and characterization of DNA polymerase $\beta$-like enzyme from Plasmodium falciparum. Mol Biochem Parasitol. 2007;154:141-7.

24. Chavalitshewinkoon-Petmitr P, Chawprom S, Naesens L, Balzarini J, Wilairat P. Partial purification and characterization of mitochondrial DNA polymerase from Plasmodium falciparum. Parasitol Int. 2000;49:279-88.

25. Fox BA, Bzik DJ. The primary structure of Plasmodium falciparum DNA polymerase delta is similar to drug sensitive delta-like viral DNA polymerases. Mol Biochem Parasitol. 1991;49:289-96.

26. Ridley RG, White JH, McAleese SM, Goman M, Alano P, de Vries E, et al. DNA polymerase delta: gene sequences from Plasmodium falciparum indicate that this enzyme is more highly conserved than DNA polymerase alpha. Nucleic Acids Res. 1991;19:6731-6.

27. Horrocks P, Jackson M, Cheesman S, White JH, Kilbey BJ. Stage specific expression of proliferating cell nuclear antigen and DNA polymerase delta from Plasmodium falciparum. Mol Biochem Parasitol. 1996:79:177-82

28. Thaithong S, Beale GH, Chutmongkonkul M. Susceptibility of Plasmodium falciparum to five drugs: an in vitro study of isolates mainly from Thailand. Trans R Soc Trop Med Hyg. 1983;77:228-31.

29. Patterson S, Whittle C, Robert C, Chakrabarti D. Molecular characterization and expression of an alternate proliferating cell nuclear antigen homologue, PfPCNA2, in Plasmodium falciparum. Biochem Biophys Res Commun. 2002;298:371-6.

30. Bradford M. A rapid and sensitive method for the quantitation of microgram quantities of protein utilizing the principle of protein-dye binding. Anal Biochem. 1976;72:248-54.

31. Rason MA, Randriantsoa T, Andrianantenaina H, Ratsimbasoa A, Menard D. Performance and reliability of the SYBR green I based assay for the routine monitoring of susceptibility of Plasmodium falciparum clinical isolates. Trans R Soc Trop Med Hyg. 2008;104:346-51.

32. Suksangpleng T, Leartsakulpanich U, Moonsom S, Siribal S, Boonyuen U, Wright GE, et al. Molecular characterization of Plasmodium falciparum uracil-DNA glycosylase and its potential as a new anti-malarial drug target. Malar J. 2014;13:149.

33. Byrnes JJ, Downey KM, Black VL, So AG. A new mammalian DNA polymerase with $3^{\prime}$ to $5^{\prime}$ exonuclease activity: DNA polymerase delta. Biochemistry. 1976;15:2817-23.

34. Pignede G, Bouvier D, de Recondo AM, Baldacci G. Characterization of the POL3 gene product from Schizosaccharomyces pombe indicates interspecies conservation of the catalytic subunit of DNA polymerase delta. $J$ Mol Biol. 1991;222:209-18.

35. Berwal R, Gopalan N, Chandel K, Prasad GB, Prakash S. Plasmodium falciparum: enhanced soluble expression, purification and biochemical characterization of lactate dehydrogenase. Exp Parasitol. 2008;120:135-41.

36. Lamers MH, Georgescu RE, Lee SG, O'Donnell M, Kuriyan J. Crystal Structure of the Catalytic a Subunit of E. coli Replicative DNA Polymerase III. Cell. 2006;126:881-92.

37. Li H, Xie B, Zhou Y, Rahmeh A, Trusa S, Zhang S, et al. Functional roles of p12, the fourth subunit of human DNA polymerase delta. J Biol Chem. 2006:281:14748-55.

38. Sun Y, Jiang Y, Zhang P, Zhang S-J, Zhou Y, Li BQ, et al. Expression and characterization of the small subunit of human DNA polymerase $\delta$. J Biol Chem. 1997;272:13013-8.

39. Wu SM, Zhang P, Zeng XR, Zhang SJ, Mo J, Li BQ, et al. Characterization of the p125 subuit of human DNA polymerase $\delta$ and its deletion mutants: interaction with cyclin-dependent kinase-cyclins. J Biol Chem. 1998;73:9561-9.

40. Aoyagi N, Matsuoka S, Furunobu A, Matsukage A, Sakaguchi K. Drosophila DNA polymerase delta purification and characterization. J Biol Chem. 1994;269:6045-50.

41. Arroyo MP, Downey K, So AG, Wang TS. Schizosaccharomyces pombe proliferating cell nuclear antigen mutations affect DNA polymerase delta processivity. J Biol Chem. 1996;271:15971-80.

42. Wright GE, Hübscher U, Khan NN, Focher F, Verri A. Inhibitor analysis of calf thymus DNA polymerases a, $\delta$ and $\varepsilon$. FEBS Lett. 1994;341:128-30.

43. Xu WC, Wright GE, Brown NC, Long ZY, Zhi CX, Dvoskin S, et al. 7-AlkylN(2)-substituted-3-deazaguanines. Synthesis, DNA polymerase III inhibition and antibacterial activity. Bioorg Med Chem Lett. 2011;21:4197-202. 